\title{
Pesticide Injection and Drenching ${ }^{1}$
}

\author{
Frederick M. Fishel ${ }^{2}$
}

Injection application may be made directly into the trunk of the tree or the soil underneath it near the roots. Injection of pesticides into a tree trunk directly applies concentrated systemic pesticides into a tree's vascular tissues for faster translocation (Figure 1). Soil injection places the pesticide below mulch or turf and directly into the root zone of the tree. Drenching is similar to soil injection, except the pesticide mixture is poured to the soil surrounding the tree. Drenching and injection have the same net benefits in that the pesticide quickly enters the tree's vascular system. These types of applications are particularly effective in controlling some of the most troublesome insect pests of ornamental landscape trees, including aphids, scale insects, and whiteflies.

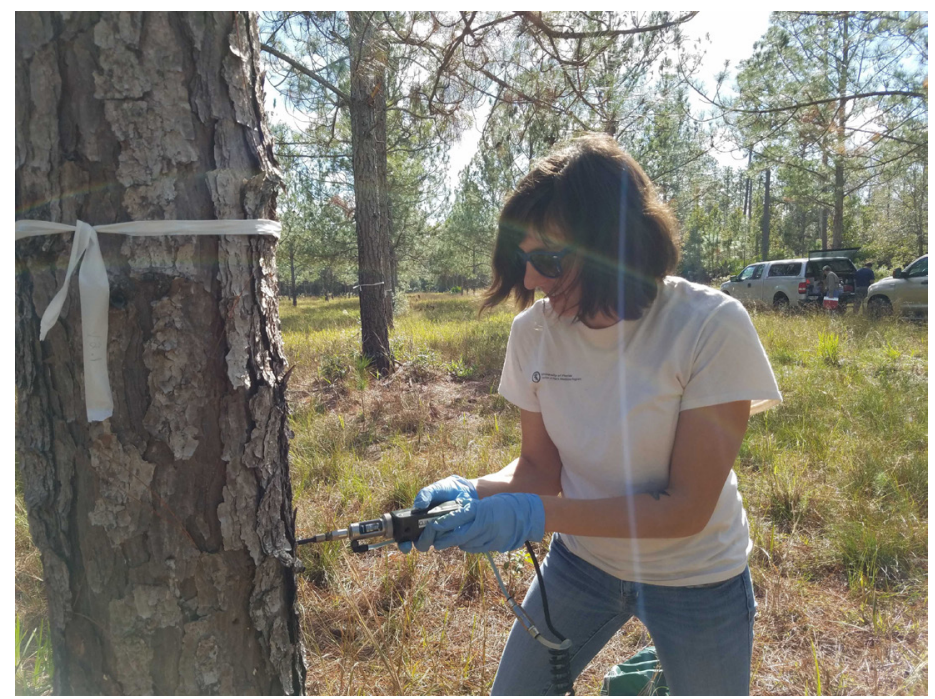

Figure 1. Injection of insecticide into a tree.

Credits: Ariane McCorquodale, UF/IFAS
A wide variety of pesticides, including plant growth regulators, are available for use by professional applicators and arborists with these technologies (Table 1). Commercial use of these application techniques in ornamental landscapes requires the proper pest control license under the Florida Department of Agriculture and Consumer Services. Check the label of any pesticide intended to be applied with any of these techniques to ensure your use is included.

\section{Drenching and Soil Injection}

Soil injection or drench methods involve placing chemicals in liquid form near the roots in the soil for root uptake. As with the other injection methods, the chemicals must be water soluble. Chemicals should be applied to moist (but not saturated) soil.

With the soil drench method, you simply pour chemical mixed in water on the soil near the tree's root crown. Mulch or other surface organic matter is pulled back and the chemical is poured directly on the soil. Then, the mulch is replaced. The amount of chemical used is based on inches of trunk diameter and will be stated on the label.

Soil injection methods vary somewhat, but typical recommendations are to inject chemicals $2-4$ inches deep with a high pressure injector either within 18 inches of the trunk or on a grid (Figures 2-3). Amounts to be applied depend on trunk diameter, and diameters are added if multiple trees are being treated in an area.

1. This document is $\mathrm{PI} 274$, one of a series of the Agronomy Department, UF/IFAS Extension. Original publication date January 2018. Visit the EDIS website at http://edis.ifas.ufl.edu.

2. Frederick M. Fishel, professor, Agronomy Department; UF/IFAS Extension, Gainesville, FL 32611.

The Institute of Food and Agricultural Sciences (IFAS) is an Equal Opportunity Institution authorized to provide research, educational information and other services only to individuals and institutions that function with non-discrimination with respect to race, creed, color, religion, age, disability, sex, sexual orientation, marital status, national origin, political opinions or affiliations. For more information on obtaining other UF/IFAS Extension publications, contact your county's UF/IFAS Extension office. 


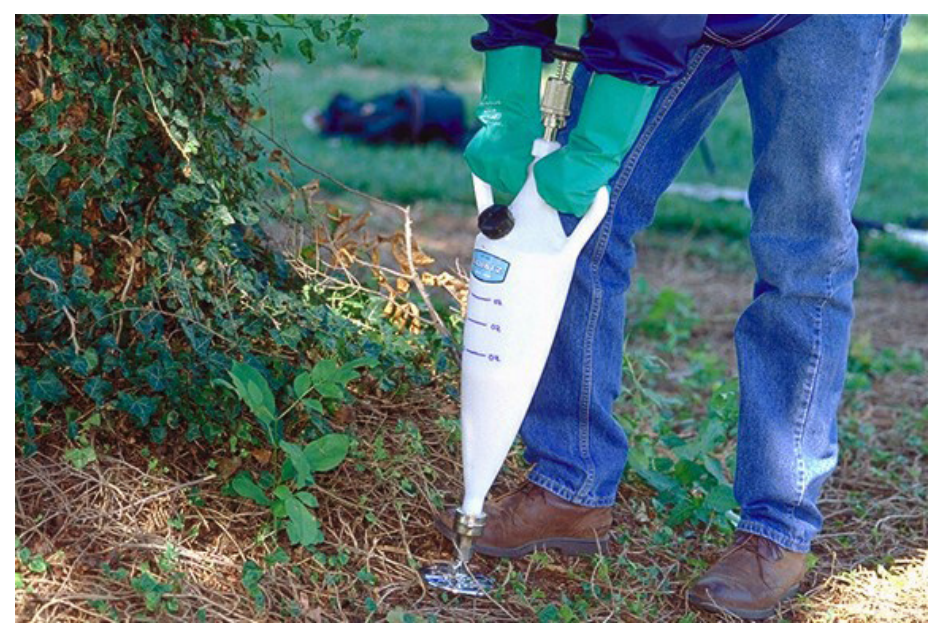

Figure 2. Soil injection using a manually-pumped, low-volume Kioritz applicator.

Credits: vtpp.ext.vt.edu

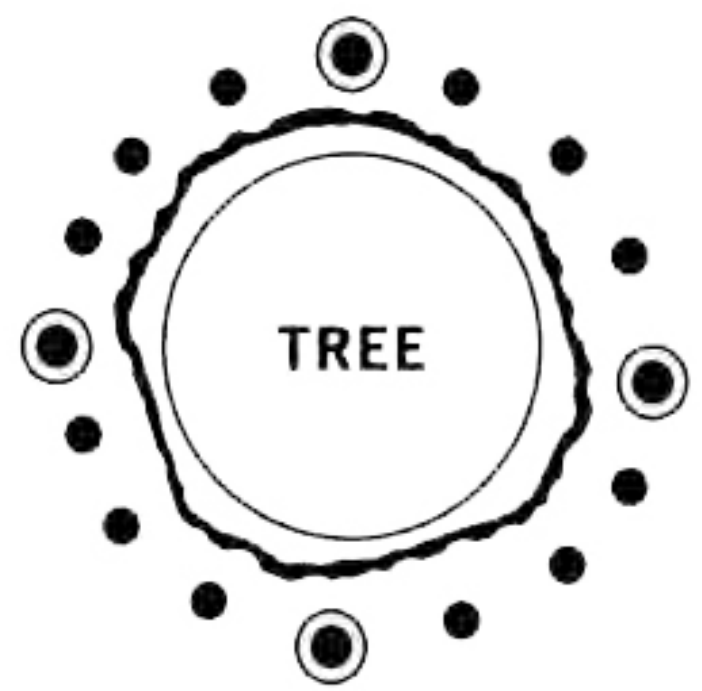

Figure 3. Grid pattern for a soil injection application. Credits: Lepitect ${ }^{\mathrm{TM}}$ product label

These methods can offer several advantages:

- Little, if any, pesticide applied is wasted to drift or runoff, because it can be applied precisely to where it is needed in the tree.

- Applications may be made during windy and rainy weather because there is no drift or runoff.

- Trunk injections can be used on sites where soil treatments may not be practical, effective, or appropriate, including trees growing on excessively wet, sandy, compacted, or restricted-soil environments.

- There is little non-target organism exposure; therefore, it can be done in environmentally-sensitive areas.

- Injection methods for treating some of Florida's troublesome piercing-sucking insects of trees, such as whiteflies and aphids, can be particularly useful.
- At least with soil injection/drenching, trees are not wounded.

- The soil drench method requires almost no tools, other than a bucket or watering can.

Disadvantages of these methods include:

- Trunk injections cause wounding and subsequent injury, or facilitate entrance of pathogens. Note that hardwoods will eventually heal over following injection, while palms will not.

- Trunk injections can be more costly and labor-intensive.

- Coverage with trunk injections can be spotty throughout the crown.

- With drenching, somewhat higher amounts of chemicals must be used than with injection.

- Trunk injection equipment can be costly.

\section{Injection Equipment}

One of the best known low-pressure systems is the Mauget $^{\mathrm{TM}}$ system (www.mauget.com), which uses plastic capsules that are pressurized by depressing a plunger that locks in place (Figure 4). The capsule then is pressed onto a tube that is already inserted into the tree, breaking a seal in the capsule and releasing the pressurized chemical. Other systems that use pressurized capsules with a similar array of chemicals include Tree Tech Microinjection Systems ${ }^{\mathrm{TM}}$ (www.treetech.net), and Rainbow Treecare ${ }^{\mathrm{TM}}$ (www.treecarescience.com). These systems require fairly small drilled holes ( $1 / 8$ " to $3 / 16$ "), are fairly simple to use, and are slower than high pressure systems.

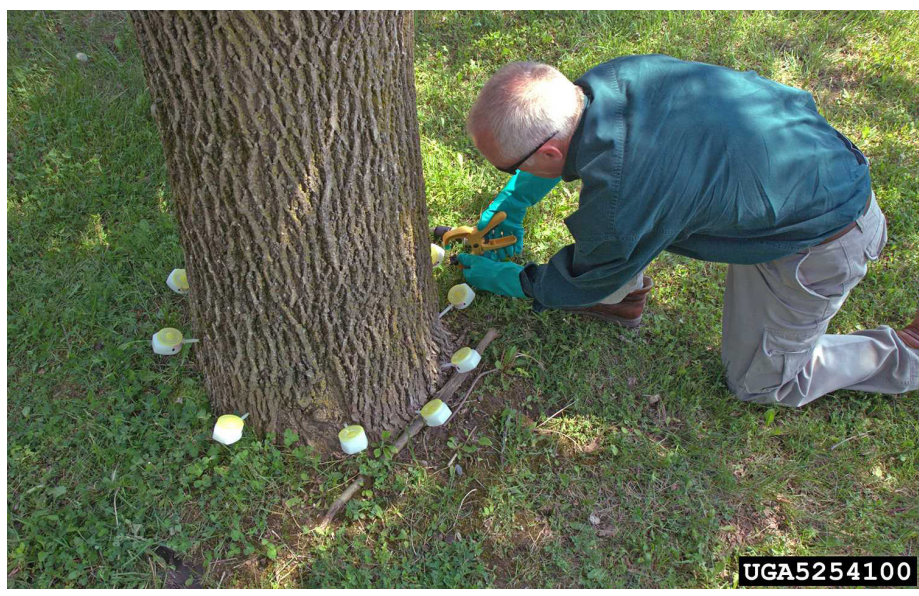

Figure 4. Tree injection using the Mauget system.

Credits: David Cappaert, bugwood.org

Higher pressure systems are available that inject chemicals using either a syringe or tubing, tees, and a chemical reservoir designed to be under pressure. These include 
the Arborjet ${ }^{\circledR}$ Tree I.V. system, which uses tees and tubing and delivers high volumes of chemicals from a pressurized reservoir; and their Quik-Jet ${ }^{\circledR}$ system, which applies small chemical volumes with a syringe (www.arborjet. com). Rainbow Treecare ${ }^{\mathrm{TM}}$ also has pressurized tubing and reservoir systems. The ArborSystem ${ }^{\mathrm{TM}}$ (www.arborsystems. com) Wedgle ${ }^{\mathrm{TM}}$ injection system doesn't use drilled holes but relies on injection through a seal with a syringe and specially designed needle. It is fairly fast because of the pressure created by the syringe.

\section{Applying the Correct Amount}

Some tree injection techniques use products that are premixed and applied through a closed system; therefore, no mixing or calibration is required. Others require direct injection into holes drilled into the bark of the tree. The dose and number of holes to drill are based on the size of the tree. The size of the tree is the diameter measured at breast height, known as "dbh," a measurement taken at 54 inches from the ground. To determine the application/dose rate per tree:

1. Measure the tree circumference in inches for the determining the dbh.

2. Divide the circumference by 3 to obtain the $\mathrm{dbh}$ in inches.

3. Calculate the number of injection sites by dividing the dbh in inches by 2 .

4. Multiply the tree dbh by the dosage rate to calculate the total dose in milliliters per tree.

5. Divide the total dose by the number of injection sites to determine required dosage per injection site.

\section{Example}

You are hired to inject palm trees with an insecticide for control of whiteflies. The product label states to apply $4 \mathrm{ml}$ per inch of trunk diameter at dbh.

\section{SOLUTION}

1. You measure the trunk's circumference to be 36 inches.

2. Determine dbh: 36 inches $\div 3=12$ inch dbh.

3. Determine the number of injection sites: 12 inches $\div 2=$ 6 injection sites.

4. Determine total dose: 12 inches $\mathrm{x} 4 \mathrm{ml}=48 \mathrm{ml}$ total dose per tree.
5. Determine amount to deliver into each injection site: 48 $\mathrm{ml} \div 6$ injection sites $=8 \mathrm{ml}$ per injection site to deliver the required dosage.

With soil injection around trees and shrubs, the dbh principle is also used to determine product dosage. Injection holes around the base of the tree are based on a grid, circle, or basal system. The grid system recommends to space holes on 2.5-foot centers, in a grid pattern, extending to the drip line of the tree. With the circle system, pesticide is injected into holes spaced evenly beneath the drip line of the tree, extending in from that line. Depending on the size of the tree, more than a single circle of holes may be necessary. The basal system spaces injection holes evenly around the base of the tree trunk, no more than 6-12 inches out from the base. The required dosage is mixed in sufficient water to inject an equal amount of solution into each hole. At least 4 holes per tree or shrub should be used.

The goal of soil drenching is to deliver the product uniformly in a specified volume of water per product label instructions around the base of the tree, directed to the root zone. A misconception is that if higher volumes of water are used, then the product will be diluted, or that putting on less water will result in a very concentrated product. However, whether 2 ounces of product are applied per thousand square feet mixed in 10 gallons or 100 gallons, there is no difference. When the application is over, two ounces of product are left behind.

\section{Example}

You are hired to treat ornamental trees with an insecticide as a soil drench for control of mealybugs. The product label states to apply 2 ounces of product per 10 feet of tree height and to apply the drench solution at a rate of 4 pints per inch of trunk diameter.

\section{SOLUTION}

1. You measure the trunk's circumference to be 36 inches and estimate the height to be 25 feet.

2. Determine dbh: 36 inches $\div 3=12$ inch $\mathrm{dbh}$.

3. Determine the amount of product to apply to the tree: 2 ounces $\mathrm{x}(25 \mathrm{ft} \div 10 \mathrm{ft})=5 \mathrm{oz}$.

4. Determine amount of drench solution: 4 pints $\mathrm{x} 12$ inch $\mathrm{dbh}=48$ pints total dose per tree.

5. Convert to gallons: 48 pints $\div 8$ pints/gal $=6$ gallons solution to deliver the required dosage. 
Table 1. Florida-registered pesticide options available for professional injection/drench applications. ${ }^{1}$

\begin{tabular}{|c|c|c|c|}
\hline Active ingredient & Pesticide class & Trade names & Method(s) \\
\hline \multirow[t]{4}{*}{ Abamectin } & \multirow[t]{4}{*}{ Insecticide/miticide } & Abacide $^{\mathrm{TM}} 2$ & \multirow[t]{4}{*}{ Trunk injection } \\
\hline & & Aracinate $^{\mathrm{TM}}$ & \\
\hline & & Greyhound $^{\mathrm{TM}}$ & \\
\hline & & Vivid $^{\oplus}$ II & \\
\hline \multirow[t]{3}{*}{ Acephate } & \multirow[t]{3}{*}{ Insecticide } & Ace-jet & \multirow[t]{2}{*}{ Trunk injection } \\
\hline & & Dendrex $^{\circledast}$ & \\
\hline & & Lepitect ${ }^{\mathrm{TM}}$ & Soil drench, soil injection \\
\hline Azadirachtin & Insecticide & AzaSol $^{\mathrm{TM}}$ & Trunk injection \\
\hline Calcium oxytetracycline & Antibiotic & Tree Tech ${ }^{\circledR}$ OTC & Trunk injection \\
\hline Dikegulac-sodium & Plant growth regulator & Pinscher ${ }^{\circledR}$ PGR & Trunk injection \\
\hline \multirow[t]{6}{*}{ Dinotefuran } & \multirow[t]{6}{*}{ Insecticide } & Dinocide $^{T M}$ & Trunk injection \\
\hline & & Dinotefuran $^{\mathrm{TM}} 10 \mathrm{SL}$ & \multirow[t]{5}{*}{ Soil drench, soil injection } \\
\hline & & Dinotefuran Tree Care ${ }^{\mathrm{TM}} 70$ WSP & \\
\hline & & Safari $^{\circledast} 20$ SG & \\
\hline & & Transtect $^{\mathrm{TM}} 70$ WSP & \\
\hline & & Zylam $^{\circledR}$ & \\
\hline \multirow[t]{4}{*}{ Emamectin benzoate } & \multirow[t]{4}{*}{ Insecticide } & Brandt $^{\circledast}$ enTree $^{\oplus} \mathrm{EB}$ & \multirow[t]{4}{*}{ Trunk injection } \\
\hline & & ArborMectin $^{\mathrm{TM}}$ & \\
\hline & & Tree-äge $^{\circledast}$ & \\
\hline & & Tree-äge ${ }^{\circledR} \mathrm{G} 4$ & \\
\hline Flurprimidol & Plant growth regulator & Mastiff ${ }^{\oplus}$ PGR & Trunk injection \\
\hline Imidacloprid & Insecticide & Many & $\begin{array}{l}\text { Specific to product (check } \\
\text { label) }\end{array}$ \\
\hline Indole-3-butyric acid & Plant growth regulator & Snipper ${ }^{\circledast}$ & Trunk injection \\
\hline Mefenoxam & Fungicide & Subdue ${ }^{\circledast}$ Maxx $^{\circledast}$ & Soil drench \\
\hline \multirow{3}{*}{$\begin{array}{l}\text { Mono- and di- potassium salts of } \\
\text { phosphorous acid }\end{array}$} & \multirow[t]{3}{*}{ Fungicide } & ArborFos $^{\mathrm{TM}}$ & \multirow[t]{3}{*}{ Trunk injection } \\
\hline & & Phospho-jet & \\
\hline & & Whippet $^{\circledR}$ & \\
\hline Oxydemeton methyl & Insecticide & Harpoon $^{\circledast}$ & Trunk injection \\
\hline \multirow[t]{4}{*}{ Oxytetracycline hydrochloride } & \multirow[t]{4}{*}{ Antibiotic } & Arbor-OTC ${ }^{\mathrm{TM}}$ & \multirow[t]{4}{*}{ Trunk injection } \\
\hline & & Mycoject ${ }^{\circledast}$ Ultra & \\
\hline & & Springer ${ }^{\mathrm{TM}}$ & \\
\hline & & Terrier $^{\mathrm{TM}}$ & \\
\hline \multirow[t]{2}{*}{ Paclobutrazol } & \multirow[t]{2}{*}{ Plant growth regulator } & Cambistat $^{\mathrm{TM}}$ & \multirow[t]{2}{*}{ Soil drench, soil injection } \\
\hline & & Trimtect $^{\circledast}$ & \\
\hline \multirow[t]{4}{*}{ Propiconazole } & \multirow[t]{4}{*}{ Fungicide } & Alamo $^{\circledast}$ & \multirow[t]{4}{*}{ Trunk injection } \\
\hline & & Alsa & \\
\hline & & Propizol $^{\circledR}$ & \\
\hline & & Shepherd ${ }^{\circledR}$ & \\
\hline \multirow[t]{2}{*}{ Tebuconazole } & \multirow[t]{2}{*}{ Fungicide } & Brandt $^{\circledast}$ enTree $^{\circledast}$ Tebu RTU & Trunk injection \\
\hline & & Tebuject $^{\mathrm{TM}} 16$ & \\
\hline Thiabendazole & Fungicide & Arbotect $^{\circledR} 20-S$ & Trunk injection \\
\hline Triadimefon & Fungicide & Systrex ${ }^{\circledast} /$ Nutrient & Trunk injection \\
\hline
\end{tabular}

